\title{
The Brazilian Beauty Industry and the Cosmetics Market For Frizzy / Curly Hair
}

\author{
Jeane Rosa Gomes \\ Post-graduate MBA in Business Management and Innovation \\ State University of Goiás- Brazil \\ Francisco Alberto Severo de Almeida \\ State University of Goiás-Brazil \\ Jorge Manoel Adão \\ State University of Goiás-Brazil \\ Marcelo Duarte Porto \\ State University of Goiás-Brazil \\ Ronaldo Rodrigues da Silva \\ StateUniversityof Goiás-Brazil
}

\begin{abstract}
This research aimed to get to know the beauty industry and aspects of the creative economy focused on social and cultural movements, as well as cosmetics market consumers' perception fated to the public with frizzy / curly hair. The research is exploratory and descriptive, based on bibliographical, documentary and field research. The field research instrument, applied to 100 (one hundred) consumers of products for frizzy and curly hair, was organized and structured to identify the profile of consumers of cosmetics for frizzy / curly hair, as well as to contextualize the conditioning paradigms of the marketing compound in the beauty industry. Finally, I concluded that the culture of affirming the use of frizzy/ curly hair in a natural way is a niche market that will demand from the beauty industry in the next decades, without a doubt, marketing strategies for the formation of portfolios of cosmetic products for this segment of the market.
\end{abstract}

Keywords: Beauty industry. Marketing Compound. Creative Economy.

\section{Introduction}

In recent years there has been a change in the behavior of the audience with frizzy / curly hair due to increased knowledge of the dangers and damage to health caused by long-term flatting and also by the actions of black social movements regarding the valorization of their natural hair. In this context, it is observed the growth of the segment of this population that is returning to use hair naturally frizzy / curly and seeking options of products to take care of their hair. According to the cosmetics portal $\mathrm{Br}$ (2015, page 03), an international portal dedicated to the cosmetics industry, "This movement has grown about 30\% each year in Brazil thanks to the demand of the black consumer who is accepting more of her curls beyond the influence of famous artists and singers". Therefore, the cosmetics industries are turning their attention to this market and gradually adapting to the market segment for frizzy / curly hair. In this sense, knowing the consumer market for frizzy / curly hair products is important so that the beauty industry establishes strategies of competitiveness and business segmentation for this market.

The beauty industry, the branch of the creative economy focused on social and cultural movements, is betting on innovations and launching new product lines aimed at serving consumers of frizzly / curly hair cosmetics. According to the newspaper Estadão (2015) after the reign of flat iron and straightened hair, the curls come back with all their glowing, thus increasing the demand for specialized products and services. A new and growing market in which organizations need to study and understand it to gain space, visibility and promote the satisfaction and loyalty of their cosmetic consumers to frizzy / curly hair.

From this scenario, it emerges the interest of studying this frontier theme of the creative economy: the beauty industry and consumers of frizzy / curly hair cosmetics, verifying the expansion of this market. Brazil has the majority of the population with frizzy or curly hair. According to a Unilever survey, (2012) by Kantar WorldPanel, it indicates that $51.4 \%$ of Brazilian women have their hair originally frizzy or curly. Therefore, this article, through an exploratory and descriptive study, presents the result of empirical research that studies, analyzes and describes the perception of consumers in the cosmetics market segment for frizzly / curly hair. 


\section{The Culture of Frizzy Curly Hair}

Anthropology has already used hair several times to identify white, black, indigenous, among other human races, due to it referring to an aspect that is easier to analyze because it does not require physically invasive methods of analysis, thus being able to observe and to identify more quickly, this classification created a racial hierarchy still with comparison between the hairs.

[...] a wide range of colours and positive textures, such as 'fine, soft and silky' (Crawfurd 1868: 146) so that whites were handed the cultural advantage of differentiated, distinct and aesthetically pleasing identities. In contrast, [...] African 'negroid' [...] hair was described as Black and 'woolly', as in the title of Peter A Browne's Classification of Mankind by the Hair and Wool of their heads of 1852, in which Browne argued that wool-like hair qualities proved that the black race(s) were a completely separate species to whites [...].1 (CHEANG, 2008, pp. 31-32 apud QUINTÃO, 2013 p.16-17)

1 “"...] a wide range of positive colors and textures, such as 'fine, soft and silky' (Crawfurd 1868: 146), so that whites were given the cultural advantage of differentiated, distinct and aesthetically pleasing identities. On the contrary,[...] the African hair 'negroide' [...] was described as black and 'woolly', as in the title of Peter A. Browne The classification of humanity by the hair and wool of their heads of 1852, in which Browne argued that the quality of wool-like hair proved that the black breed(s) was(were) a species completely separate from the whites [...]." (CHEANG, 2008, p. 29) (Free translation, apud QUINTÃO, 2013 p.17)

Therefore, the straight hair of European white since the mid-nineteenth century is considered a type of "good" hair and frizzy/ curly hair associated with black people and their African offspring a "bad" hair. In this way, in the last century, under the dominant perspective of the beauty aesthetics of straight hair, the culture of hair straightening prevailed.

In Brazil the straightening hair process began in the 1930s. This procedure caused a lot of damage mainly due to the high temperature and by that time, the absence of the heat protector. Köhler and Beraldo (2015) describes the straightening process at the time: "Relative distant from the flat iron, the hairdresser was a metal rod taken to the fire or to the stove. Once warm, the accessory was applied to the hair and ready, it had its texture modified, but without actually eliminating the ripples, as used by the actress Greta Garbo."

Köhler and Beraldo (2015) also mention the appearance of the hot comb around the 1940s. It was an instrument similar to a hairstyler, having to heat an iron comb directly to the fire and press it immediately on the wires. In the 1950s the chemical straightening processes arise, through the use of sodium hydroxide, a product known as caustic soda, used in hairs called afros. Created in 1914 by the company called Relaxer, nevertheless, it was only in the 50s that it is popularized due to the black actresses and with bulky hair they adopted its use. It is noted, then, how painful and harmful health were for the first methods of hair smoothing.

In the period of the 70's and 80's, Black Power hair reached a large number of fans. The movement found its peak, seeking to enhance curly/frizzy hair as a symbol of black resistance, in this context, Domingues states:

Until that time it was considered only positive, the white cultural models that came from Europe. To reject this process of alienation, the protagonists of the blackness ideology came to rescue and enhance the values and cultural symbols of African matrix. (DOMINGUES, 2005, p.5).

Various artists have adopted the visual black power of the American black movement: The Supremes, The Jackson Five, James Brown. In Brazil the outstanding styles of Toni Tornado, Tim Maia, ElzaSoares and Gilberto Gil portrayed this time.

When entering the 90's the curly and armed hair began to disappear and the straight one came back to being the stereotype to fit the standards of beauty. The chemical engineer specialist in cosmetology Humberto Michel commented in an article for hair \&cia magazine about this period when new techniques of hair straightening appeared:

In addition to the popularization of the flat iron, it was born to the trend created by the hairdresser Satoru Nagata, who improved a Turkish technique and called it Japanese straightening (which is also called a permanent hair brushing)! Based on ammonium thioglycolate, the process damaged the hair strands a lot and had an artificial result. It was a lot of aggression because, in addition to passing the product, it was necessary to rinse it and flat iron it many times, sensitizing and breaking the locks, especially in the root retouch. In Brazil, the actress Malu Mader and the then anchor of the National Newspaper, Fatima Bernardes, joined the fashion. (MICHEL, 2015). In the year 2000s the permanent hair brushing was losing space for formalin straightening until formalin was banned by the National Sanitary Surveillance Agency (2009). According to Resolution RDC 36 of June 17, 2009, it was prohibited to trade formaldehyde after it was proven that continued use caused several health damages, from a simple itching or irritation to the most serious cases such as cancer in the upper airways, even leading to death. 
Nevertheless, in the last decade the movement for the return of the natural hair gained strength through the black social movements and its exponents, having as pioneer the several famous personalities of the media, scenic arts, among them, TaísAraújo, Débora Nascimento, Sheron Menezzes to the reporter Maria Júlia Coutinho and several other professionals and artists from the world of culture.

The more the movement back to natural hair grew, the more reports came about how the return to the original hair brought changes not only in appearance and self-esteem, but also health. The reports of Tainá Cristina Quitério and Bruna Caroline de Abreu, both students, describe a process of overcoming and acceptance:

Tainá Cristina Quitério, a 21-year-old student, straightened her hair since she was five and stopped eight months ago. I had never seen my natural hair. My mother always straightened it. When I stopped, she stopped too. I'm liking the results. Back in the days it was very difficult to find hair products, but nowadays it is much easier, at any pharmacy I can find it. (Journal The Day, 2014).

Since the age of 12, for the student Bruna Caroline de Abreu, there was only one alternative: to calm the personality of curly, and sometimes rebellious, strips of hair with chemical straightening. The limit happened when the young woman made the already recurring Brazilian blowout. He left the salon as usual, but he had a surprise in the morning. When he woke up, he found the pillow stained with blood, as a result of a strong allergic reaction to the procedure. From then on, he decided to take over the curls, once and for all. (Jornal Correio Brasilense, 2016).

To take on natural hair it is required a deconstruction of what is imposed as an ideal beauty standard. In the two reports above it can be seen that ever since their childhood the two students Tainá Cristina and Bruna Caroline straightened their hair, being then a great and courageous change the abandonment of the hair straightening techniques. At the moment that the decision to return to natural hair exists, it is necessary to go through a process called hair transition. According to the magazine Mdemulher (2015), hair transition "is the period in which the woman lets her natural hair grow from the root until it reaches an ideal length for the so-called big chop (or BC), the large cut that pulls all the straight ends. The bravest ones decide to shave their hair or cut it very short, letting everything grow new!

Therefore, when a person decides to assume and take care of their frizzy or curly hair, it is normal for them to take a little time to find the right type of product for their type of hair strip. There are several new lines, products and procedures that come to please the frizzy/ curly consumer.

However, it should be noted that what matters is the acceptance of hair as it really is. Ster Nascimento (2015) points out that hair is an extension of our body. "I know what my hair means to me, and I know how happy I am to have it and assume it. But each lived a different history, each person has its own taste, personality and style.

\section{The product market for frizzy/curly hair}

According to Porter (1989) for a company to be able to differentiate itself from the competition it has to offer something singular, important and with a price in account. One of the biggest curses of the public with frizzy and curly hair, especially for those who are starting to take on their natural hair is to believe that taking care of curly hair requires a series of expensive products and techniques that require a lot of time. According to Sousa (2015) "Who can pay a little more for a hair product, finds great options. Those who cannot or do not want to spend too much can also get good alternatives." Although the market for products aimed at the frizzy and curly hair public is on the rise, marketing campaigns advertisement are still low and in many times the hair and the models used in these advertisements do not fit the reality.

Brands do not just have the challenge of creating good products: products need to match their audience. Just like your advertisements and all your publicity work. I want to see me really curly, no more hair plugs, no more curlers! I want to be able to see myself in the advertisements. I want to identify myself, after all, representativeness, it matters! (Blog Cacheia, 2016.)

However, the acceptance and caring with frizzy / curly hair is a subject that has been debated in various blogs, social networks and channels on youtube, whose focus is directed to teach techniques on how to fix frizzy / curly hair; how to use the products correctly, by applying techniques of washes, day-to-day or party hairstyles; as well as keep your hair healthy and moisturized. In addition, there are also techniques and features adapted for the hair transition that assist in the change from straight hair to natural hair.

The beauty industry, with an eye in this public who learns to take care of hair virtually, bets on the promotion and dissemination of its product lines in the channels of social networks, associating its brand and products to the procedures of prewash, washing, hydration, nutrition, reconstruction, conditioning and finishing. According to Kotler (2002: 250) "Information on the internet will flow around the globe in an instant. Suppliers will identify potential buyers, and buyers will be able to identify the best suppliers and products. "

130 
Finally, it should be noted that this virtual movement also contributes to the awareness that natural hair may not always be the most beautiful. But, however, they teach respect for natural hair as it really is. The blog "Frizzy/Curly Hair is Good Hair" by journalist Mariângela Miguel aims to show that curly hair is just as good as straight hair. Another blog "curly girl stuff" by Youtuber and Blogger Gill Vianna aims to show that it is possible to have beautiful and wellgroomed curly hair without having to resort to beauty salons.

The market for frizzy curly hair products is a challenge for the beauty industry in formulating competitive marketing strategies for a market segment that has grown by around 30\% a year in Brazil. In this context, the newspaper El País portrays well the capacity of the cosmetic industry to reinvent itself in relation to the culture market of frizzy and curly hair:

The industry is constantly reinventing itself. Deep inside, the trend of frizzy hair is part of a larger niche, slowbeauty, a concept that deals with conscious consumption. People begin to question the quality and safety of what goes through the skin, hair, because there is a greater concern with health (El País, 2015).

\section{Competitiveness and marketing in the context of the creative economy}

According to Prahalad and Hamel (1998), a company's competitiveness derives from its price / performance attributes on existing products. For Porter (1989), competitive strategy seeks to establish a profitable and sustainable position against the forces that determine competition in industry. In this sense, it is considered important to adopt a competitive position for companies as a way of differentiating themselves from current and future competitors, according to the perception and understanding of the customers. For Moreira and Oliviere Neto (1998) it is through the competitive process that companies seek basic growth strategies, increase of market share and maximize profitability. Meriño and Chordá (2005) emphasize that the understanding on competitiveness must take into account the following factors of competence: towards somewhere; in quality management; in human resources; in marketing management; in technology management; in organization; in productive system; in costs and financing.

On the other hand, Marketing has as attributes the development of marketing strategies of the company, from the design to the development, deployment and evaluation of a particular product or service with the consumer. Almeida (2000) defines marketing as a process of administrative and social management, where the organization is attentive to the needs and desires of its consumers, creates a product and / or service and establishes a relationship of exchange of values with its target market. For Cobra (1993);Richers (2000) marketing translates itself into the way of feeling, understanding and serving the market. According to Kotler (1999), marketing has as its main responsibility the achievement of growth in profitable revenues for the company. Another point is that marketing establishes a direct relationship between the customer and the company. Customers attribute values to products and services in the direct proportion that these products have to meet their Wing (1998) requirements. The Dimensions of Creative Economy chart and the use of marketing techniques portrays how to establish a crossing between corporate strategy, the cosmetics market and the beauty industry in relation to marketing techniques. 
Table 1 - The dimensions of Creative Economy and the use of marketing techniques

\begin{tabular}{|c|c|c|c|c|}
\hline \multicolumn{2}{|c|}{$\begin{array}{c}\text { Dimensions of Creative } \\
\text { Economy }\end{array}$} & Corporate Strategy & The Beauty Market & The Beauty Industry \\
\hline \multirow{5}{*}{ 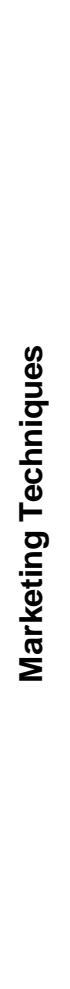 } & Strategic planning & $\begin{array}{l}\text { Formulation of corporate } \\
\text { business strategy }\end{array}$ & $\begin{array}{l}\text { Formulation of portfolio } \\
\text { strategy of cosmetic } \\
\text { products }\end{array}$ & $\begin{array}{c}\text { Formulation of competitive } \\
\text { marketing strategies }\end{array}$ \\
\hline & Marketing Research & $\begin{array}{l}\text { Market research to identify } \\
\text { the demand for products }\end{array}$ & $\begin{array}{l}\text { Research on new trends } \\
\text { to strengthen the portfolio } \\
\text { of cosmetic products }\end{array}$ & $\begin{array}{l}\text { Sales effort research of } \\
\text { products; sales } \\
\text { organization; distribution } \\
\text { and advertising; }\end{array}$ \\
\hline & - Market segmentation & $\begin{array}{c}\text { Formulation of the strategy } \\
\text { of target market strategy }\end{array}$ & $\begin{array}{l}\text { Product portfolio focused } \\
\text { on market opportunity and } \\
\text { focused on consumer } \\
\text { demand }\end{array}$ & $\begin{array}{l}\text { Establish marketing } \\
\text { strategies and } \\
\text { management tactics for } \\
\text { the product portfolio }\end{array}$ \\
\hline & Marketing Compound & $\begin{array}{c}\text { Definition of competitive } \\
\text { marketing compound for } \\
\text { the target market segment }\end{array}$ & $\begin{array}{c}\text { Definition of the tangible } \\
\text { and intangible attributes } \\
\text { that determine the product } \\
\text { to be offered }\end{array}$ & $\begin{array}{l}\text { Product Portfolio Analysis: } \\
\text { Profit, Growth, Risk, } \\
\text { Demand and Resource } \\
\text { Utilization }\end{array}$ \\
\hline & Market positioning & $\begin{array}{l}\text { Definition of the strategic } \\
\text { focus to create } \\
\text { competitive advantages }\end{array}$ & $\begin{array}{c}\text { Establish differential of } \\
\text { products with competitive } \\
\text { advantage }\end{array}$ & $\begin{array}{l}\text { Explore the competitive } \\
\text { advantage of the product } \\
\text { differential }\end{array}$ \\
\hline
\end{tabular}

Source: Adapted from Almeida (2001)

The market approach is focused on the aspects about market segmentation; marketing compound and market positioning. Market segmentation as the division of a total market for products and / or services into smaller parts of the market on a demographic, geographic, psychographic, and behavioral basis (Etzel, Walker and Stanton (2001); (Kotler (1994); Cobra (1992); Wesinsten (1995)). The marketing compound is described as the set of tangible and intangible attributes that designates the essential characteristics of the offer of a given product to the consumer. It is the result of the following elements: price, product, distribution, and communication (eg, sales, product, distribution, and communication) (Almeida (2001); Kotler (1994); Cobra (1993); Semenik e Bamossy (1995)). The market positioning comprises the action of developing strategies selected and focused on a set of significant differences, related to products or services offered, leading the consumer to value and make an association with the company's image (Moreira and OlivieriNeto (1998); Semenik and Bamossy (1995); Richers (2000)

\section{Methodology}

The methodology of the research is exploratory and descriptive, with bibliographical basis and field research. According to Zamberlan (2008, p 40), "The purpose of exploratory research is to explore a problem or a situation to provide criteria and understanding." Further, "Exploratory studies are performed from secondary data (already available)" (Samara and Barros, 2002, p.29). In this context, it was sought to raise the history and the cultural related to frizzy / curly hair and the movement for the use of natural hair. On the other hand, a retrospective on the frizzy and curly product market, as well as an approach on competitiveness and marketing in the context of the creative economy from the intersection of the corporate strategy construct, the cosmetic market and the beauty industry in relation to marketing techniques.

The descriptive basis of the scientific research was dimensioned through the application of a structured questionnaire to raise and understand the universe of the market related to the use of cosmetics for frizzy / curly hair based on table 2 that describes the size of the marketing compound, analysis variables and indicators of the variables and question item. 
Descriptive research is, in Malhotra's (2001, p. 86) conception, to "Describe the characteristics of relevant groups as consumers; [..] determine perceptions of product characteristics; determine the extent to which marketing variables are associated; make specific predictions."

Table 2 - Logical structure matrix: dimension, analysis variables, indicators of variables and question item

\begin{tabular}{|c|c|c|c|}
\hline Dimension & Analysis Variables & Indicators of Variables & Question Item \\
\hline 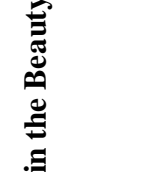 & Products & $\begin{array}{l}\text { The demand of the beauty } \\
\text { market }\end{array}$ & Key Features of a Frizzy / Curly Hair Product \\
\hline $\bar{\Xi}$ & Price & Product competitiveness & Product price factor \\
\hline ? & Marketnlace/ & & $\begin{array}{l}\text { At which points of sale do you usually buy products for } \\
\text { frizzy / curly hair? }\end{array}$ \\
\hline 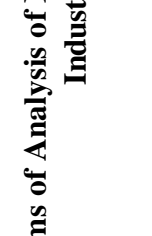 & Distribution & Distribution logistics chain & $\begin{array}{l}\text { When you want to search for some frizzy / curly hair } \\
\text { product that you have never bought before, where do you } \\
\text { usually look for information on that product first? }\end{array}$ \\
\hline 包 & $\begin{array}{c}\text { Promotion / } \\
\text { Communication }\end{array}$ & Brand Positioning & $\begin{array}{l}\text { - Opinion on the brand image; } \\
\text {-- From the media, the respondent often sees and hears } \\
\text { advertisements for frizzy / curly hair products. } \\
\text { - When choosing the product for frizzy / curly hair which is } \\
\text { less important? }\end{array}$ \\
\hline
\end{tabular}

Source: Authors

Therefore, the field research instrument, applied to 100 (one hundred) consumers of frizzy and curly hair products, was organized and structured to identify the profile of cosmetic consumers for frizzy / curly hair, as well as to contextualize the conditioning paradigms of the compound of marketing in the beauty industry, considering four (4) analysis variables, namely: the product variable identifies the demand characteristics of cosmetics for frizzy / curly hair; the price variable deals with competitiveness in relation to the price factor of the product perceived by the consumer; the variable marketplace / distribution focuses on the issue in the distribution logistic chain and, finally, the variable promotion / communication deals with the issues related to consumer perception regarding the brand positioning of products for frizzy / curly hair. The questionnaire was written in the Google application form and sent to respondents via email, WhatsApp groups and Messenger from Facebook.

\section{Summary on the socioeconomic profile of consumers of cosmetics for frizzy / curly hair}

The research showed interesting data on the profile of cosmetics consumers for frizzy / curly hair, among them, that the majority of customers are female. The sample highlights the young profile of the consumers $(91 \%)$ interviewed, whose age group is between 21 and 30 years old. It also shows that the majority of respondents $(70 \%)$ are consumers of cosmetics for frizzy / curly hair for approximately 5 (five) years. Such evidence confirms the change of habit by the use of natural hair in the last decade by young people with frizzy and curly hair. Another point to highlight, refers to the monthly income of the group surveyed (86\%) who perceive up to 3 minimum wages. In this context, it is verified that the payment method most used by the respondents (77\%) to purchase their products is through the cash mode: cash / debit card. Only $12 \%$ make use of payment by credit card. 


\section{Summary on the perception of the consumers in relation to the cosmetics of products for frizzy / curly hair}

The consumers' perception regarding frizzy / curly hair cosmetics, verified by responses of 100 (one hundred) consumers of products for frizzy and curly hair, had as reference the conditioning paradigms of the analysis of the marketing compound (product, price, marketplace and promotion) in the beauty industry. The data collection instrument was structured on the five-point Likert scale, with closed questions and with the following categories: I have no opinion, never, rarely, almost always and always. In order to analyze the results (Table 1) the criterion of grouping the answers into three modalities was adopted: degree of disagreement, with the junction of the results I have no opinion and never; neutrality, with the positioning concerning opinion rarely; and, degree of agreement, considering the sum of positions almost always and always.

\begin{tabular}{|c|c|c|c|c|c|c|}
\hline \multirow{3}{*}{$\begin{array}{l}\text { Analysis } \\
\text { Variable }\end{array}$} & \multirow{3}{*}{ Indicator } & \multirow{3}{*}{ Questionnaire Item } & \multicolumn{4}{|c|}{\begin{tabular}{|c|} 
Customer perception \\
\end{tabular}} \\
\hline & & & \begin{tabular}{|c|} 
Degree of \\
disagreemen
\end{tabular} & Neutral & $\begin{array}{c}\text { Degree of } \\
\text { agreement }\end{array}$ & NR \\
\hline & & & \% & $\%$ & $\%$ & $\%$ \\
\hline \multirow{3}{*}{ Product } & & $\begin{array}{l}\text { Does the texture of the frizzy / curly hair } \\
\text { product influence in time of purchase? }\end{array}$ & 4 & 10 & 85 & 1 \\
\hline & $\begin{array}{l}\text { The demand of the } \\
\text { beauty market }\end{array}$ & & & & & \\
\hline & & $\begin{array}{l}\text { Is it important that the frizzy / curly hair } \\
\text { product has a good fragrance? }\end{array}$ & 2 & 10 & 88 & \\
\hline \multirow{5}{*}{ Price } & & $\begin{array}{l}\text { Does price influence product quality for } \\
\text { frizzy / curly hair? }\end{array}$ & 13 & 21 & 66 & \\
\hline & $\begin{array}{l}\text { Product } \\
\text { competitiveness }\end{array}$ & $\begin{array}{l}\text { If there is a substantial increase in the } \\
\text { price of the frizzy / curly hair product brand } \\
\text { of your choice, would you continue to buy } \\
\text { it? }\end{array}$ & 12 & 24 & 64 & \\
\hline & & $\begin{array}{l}\text { Would you take a frizzy / curly hair product } \\
\text { on sale even if you do not need it? }\end{array}$ & 18 & 24 & 58 & \\
\hline & & $\begin{array}{l}\text { Do I usually buy products for frizzy / curly hair } \\
\text { in physical stores? }\end{array}$ & 1 & 2 & 97 & \\
\hline & & $\begin{array}{l}\text { Do I usually buy frizzy / curly hair products on } \\
\text { the internet? }\end{array}$ & 47 & 30 & 23 & \\
\hline \multirow{4}{*}{$\begin{array}{l}\text { Marketplace/ } \\
\text { Distribution }\end{array}$} & Distribution logistics & $\begin{array}{l}\text { Do I usually buy frizzy / curly hair products by } \\
\text { cosmetics catalog? }\end{array}$ & 50 & 26 & 24 & \\
\hline & & $\begin{array}{l}\text { Do I usually buy frizzy / curly hair products } \\
\text { through the internet, cosmetics catalog and } \\
\text { in physical stores? }\end{array}$ & 37 & 24 & 38 & \\
\hline & & $\begin{array}{l}\text { Do I usually buy frizzy / curly hair products } \\
\text { over the internet only when I do not find it in } \\
\text { physical stores? }\end{array}$ & 45 & 23 & 32 & \\
\hline & & $\begin{array}{l}\text { Has advertising campaigns already } \\
\text { influenced you when choosing a product } \\
\text { for frizzy / curly hair? }\end{array}$ & 7 & 30 & 63 & \\
\hline \multirow[t]{2}{*}{$\begin{array}{l}\text { Promotion / } \\
\text { Communication }\end{array}$} & Brand Positioning & $\begin{array}{l}\text { Do frizzy / curly hair care tutorials on } \\
\text { youtube channels or social networks have } \\
\text { already influenced you in choosing a } \\
\text { product to have frizzy / curly hair? }\end{array}$ & 11 & 9 & 80 & \\
\hline & & $\begin{array}{l}\text { Is the package important in presenting a } \\
\text { product for frizzy / curly hair? }\end{array}$ & 11 & 19 & 70 & \\
\hline
\end{tabular}

Degree of disagreement expresses attitudes regarding having no opinion and never 2) The neutral positioning is described by the attitude rarely 3) Degree of agreement expressed attitudes like almost always and always NR) Did not respond Source: Authors' elaboration

The research results show that for consumers surveyed, the texture of the product always influences in time of purchase $(85 \%)$, and considers it important that the frizzy / curly hair product has a good fragrance (88\%).

On the other hand, in the perception of the interviewed (66\%), the price almost always influences the quality of the product for frizzy / curly hair. However, when there is a substantial increase in the price of the curly hair product brand of consumer preference, (64\%) stated that they would continue to buy the desired brand. Consumers (54\%) are also willing to take a product for frizzy / curly hair on sale, even if they do not need it. Regarding the points of sale, from cosmetics for frizzy / curly hair there is an option (97\%) for shopping in physical stores. 
For the interviewed (63\%), the advertising campaigns influence when choosing a product for frizzy/curly hair. It is also worth mentioning, in the opinion of the respondents $(80 \%)$, the influence of frizzy/curly hair care tutorials on youtube channels or social networks when choosing a product for frizzy / curly hair. Another positive point regarding the communication / propagation aspect refers to the degree of agreement that respondents (70\%) give to the presentation of the product packaging for frizzy / curly hair.

\section{Final Considerations}

In the historical context one can see how devalued frizzy/ curly hair was over time. However, there are two moments when frizzy / curly hair stands out as the default: at the height of black power fashion in the 1980s, when artists struck by black social movements have taken over the natural threads, and now in recent years. It is hoped that this movement to take on the naturally frizzy / curly hair that has emerged in recent years is not just another fashion trend that soon passes, but is an acceptance of the different natural traits in each person.

When analyzing the beauty industry market for frizzy / curly hair, there is evidence regarding the rise of this market.This market segment is new and promising: consumers learning to take care of their frizzy / curly hair in its natural form and the beauty industry seeking to understand the consumer behavior as a way of positioning its brand and loyalty of the customer of cosmetics for frizzy / curly hair. The profile of the consumers is of young people between 21 and 30 years old, most female and consumer of these products between 1 and 5 years.

With regard to the analysis of data on consumer perceptions regarding frizzy / curly hair products cosmetics, based on the paradigm conditioning the analysis of the marketing compound (product, price, marketplace and promotion) in the beauty industry, the following evidences are observed: a) the texture of the product and the fragrance are important elements for the decision to acquire a cosmetic for frizzy / curly hair; b) price is a determining factor for the consumer who buys a frizzy / curly hair product, but this consumer is willing to continue to buy his preferred brand in the face of the price increase; c) in reference to the distribution channel there is a predominance on the part of consumers of cosmetics for frizzy / curly hair to make their purchases in physical stores. However, they recognize that they are influenced by frizzy/curly hair care tutorials on youtube channels or social networks, when choosing a product of a particular brand; d) in relation to the promotion, promoting the brand is the spotlight to the communication channels via social networks, as well as relying on the opinion of friends and acquaintances when you have to buy a new product.

Finally, this study does not exhaust the borders of knowledge about the beauty industry in the context of the creative economy. The paradigmatic view researched in relation to the determinants of the marketing compound, as far as the frizzy / curly hair cosmetics market is concerned, represents only a pinched light beam of this part of the Brazilian universe of consumers. Therefore, the culture of affirming the use of frizzy / curly hair in a natural way is a niche market that will demand from the beauty industry in the next decades, without a doubt, marketing strategies for portfolio formation of cosmetic products for this segment of the market.

\section{References}

ALMEIDA, Francisco A. S. Marketing Aplicado à Gestão Educacional. Universidade Estadual de Goiás, Uniciência, Anápolis, v.7, nº 1 e 2, p. 53-78, 2000

ANTUNES, R. DRUCK, G. Os Sentidos do Trabalho. 12a reimpressão. São Paulo: Boitempo,2010.

BRASIL, País dos cachos. Unilever, 29 de nov. 2012. Disponível em 〈http://www.unilever.com.br〉. Acesso em 20 de jun. 2016.

CABELOS cacheados e crespos estão em alta e ganham atenção da indústria de beleza. Estadão, 7 de maio de 2015. Disponível em <http://vida-estilo.estadao.com.br/>. Acesso em 05 de jul. 2016.

CABELOS étnicos finalmente valorizados. Cosméticos br, São Paulo, 14 de set. 2014. Disponível em: <http:// www.cosmeticosbr.com.br>. Acesso em 20 de maio 2016.

CATARINA, Ana. Resenha cachos poderosos - GarnierFructis. 26 de jun. 2015 Disponível em < http://cacheia.com/> Acesso em 23 de jul. 2016.

COBRA, Marcos. Marketing competitivo. São Paulo, Atlas, 1993.

COBRA, Marcos. Administração de marketing. 2 ed. São Paulo: Atlas, 1992.

Marcos. Marketing básico. São Paulo: Atlas, 1997.

CORTEZ, Ana Carolina. Youtubers movimentam mercado dos cabelos cacheados na internet. El País, São Paulo, 3 nov.2015. Disponível em: 〈http://brasil.elpais.com>. Acesso 17 de maio 2016.

COSMÉTICOS veganos. Blog cacheia. 16 de fev. 2015. Disponível em <http://cacheia.com/> Acesso em 10 de jul. 2016.

COSTA e SILVA, Adriana. Branding \& Design: Identidade no varejo. Rio de Janeiro: Rio Books, 2002. 
CHURCHILL, Gilbert A.; PETER, J. Paul .Marketing: criando valor para os clientes. Tradução da 2a. ed. São Paulo: Saraiva, 2005.

G. A. ; PETER, J. P. Marketing: criando valores para clientes. 2 ed. São Paulo:

DOMINGUES Petrônio. Movimento da negritude: uma breve reconstrução histórica. Mediações - Revista de Ciências Sociais. Londrina. 2005. Disponível em < http://docplayer.com.br//>. Acesso em 08 de jul. 2016.

ETZEL, Michael J., Bruce J.Walker e William J.Stanton , Marketing ; tradução técnica Arão Sapiro, São Paulo ,Makron Books, 2001

FORMOL e Glutaraldeído como alisantes - Diga NÃO ao Uso Indevido. Agência Nacional de vigilância sanitária. Brasília, 3 de jul. 2009. Disponível em < http://revistacabelos.uol.com.br/> Acesso em 09 de set. 2016.

GARNIER Fructis Vitaminados. Garnier. 2013. Disponível em < http://www.garnier. com.br/>> Acesso em 22 de jul. 2016.

GARNIER cachos poderosos. Garnier. 2014. Disponível em < http://www.garnier. com.br/>. Acesso em 22 de jul. 2016.

GIL, Antônio C. Como elaborar projetos de pesquisa. 4 ed. São Paulo: Atlas, 2007.

KÖHLER, R. BERALDO, R. A história do alisamento através das décadas. São Paulo: Segmento, 2015.

KOTLER, Philip Administração de Marketing. Análise, Planejamento, Implementação e Controle. São Paulo: Atlas, 1997.

Philip. Marketing para o século XXI: como criar, conquistar e dominar mercados. São Paulo: Futura, 1999.

Philip. Marketing para o século XXI: como criar, conquistar e dominar mercados.São Paulo: Futura, 2002.

Administração de Marketing: a edição do novo milênio. 10 ed. São Paulo: Prentice Hall, 2000.

ARMSTRONG, Gary. Princípios de Marketing. Rio de Janeiro: Prentice Hall Brasil, 12 ed. 1980.

ARMSTRONG, G. Princípios de Marketing. 12 ed. São Paulo: Pearson Prentice Hall, 2007.

KELLER, K. L. Administração de Marketing. 12 ed. São Paulo: Pearson Prentice Hall, 2006.

LAKATOS, E. M.; MARCONI, M. A. Fundamentos metodologia científica. 4 ed. São Paulo: Atlas, 2001.

LAS CASAS, Alexandre Luzzi. Marketing: Conceitos, Exercícios, Casos. São Paulo: atlas, 4 ed. 1997.

MALHOTRA, N.K. Pesquisa de marketing: uma orientação aplicada. 3. ed. Porto Alegre: Bookman, 2001

, N.K. et tal 2005. Introdução à Pesquisa de marketing. São Paulo: Pearson Education do Brasil, 2005.

MARCONI, Marina de Andrade; LAKATOS, Eva Maria. Fundamentos de metodologia científica. 7 ed. São Paulo: Atlas, 2010.

MATTAR, FauzeNajib. Pesquisa de marketing. 3 ed. São Paulo: Atlas, 2001

MERIÑO,Chordá.Gestión para lacompetitividaden empresas de lasproduccionesmecánicas, una aplicaciónpráctica , UEG, Revista Plurais, v. 1, n ${ }^{\circ}$ 2, Anápolis, p.9-44, 2005

MICHEL Humberto. A história do alisamento através das décadas. Cabelos\&cia, São Paulo, 26 de dez. 2015. Disponível em <http://revistacabelos.uol.com.br/> Acesso em 09 de set. 2016.

MAXIMIANO, Antonio Cesar Amaru. Teoria Geral da Administração: da revolução urbana à revolução digital. 6 ed. - São Paulo: Atlas, 2006.

MENDES, Danny. Resenha linha \#todecacho. 14 de fev. 2016. Disponível em <http://www.umapretaafiada.com.br/>Acesso em 22 de jul. 2016.

MOREIRA, Júlio C. T.;Olivieri Neto, Rafael. Marketing Business to Business: é fazeroumorrer, São Paulo, Makron Books, 1998

MULHERES descobrem a beleza de manter os cabelos naturalmente crespos. Correio braziliense. Brasília, 04 de ago. 2016.. Disponível em <http://www.correiobraziliense.com.br/>. Acesso em 04 de ago. 2016

PORTER, Michael. Estratégia competitiva: técnicas para análise das indústrias e da concorrência. 7. ed. Rio de Janeiro: Campus, 1991.

, Michael. Vantagem competitiva: criando e sustentando um desempenho superior.15 ed. Rio de Janeiro: Campus, 1989.

POSSO alisar o meu cabelo? Blog cacheia. 15 de jun. 2015. Disponível em <http://cacheia.com/>Acesso em 10 de set. 2016.

PRAHALAD, C. K.; HAMEL, Gary. A competência essencial da corporação.

In: MONTGOMERY, Cynthia; PORTER, Michael (org). Estratégia: a busca da vantagem competitiva. Harvard Business Review Book tradução de Bázan Tecnologia e Lingüística, Rio de Janeiro , Campus , 1998

PRODUTOS capilares, mercado e consumo. Blog cacheia. 5 de jun. 2015. Disponível em < http://cacheia.com/>Acesso em 20 de ago. 2016. 
QUINTÃo Adriana M. P. Que ela tem na cabeça? Um estudo sobre o cabelo como performance identitária. Niterói: Universidade Federal Fluminense, 2013. Disponível em <http://kilombagem.org//>. Acesso em 05 de jul. 2016.

REVISTA CABELOS, 5 coisas sobre transição capilar que você precisa saber. In: Mdemulher. São Paulo, 5 de maio. 2015. Disponível em < http://revistacabelos.uol.com.br/> Acesso em 09 de set. 2016.

REVOLUÇÃO na indústria de cosméticos para cabelos crespos. Blog cacheia. 17 de jan. 2016. Disponível em $<$ http://cacheia.com/> Acesso em 18 de ago. 2016.

SALON line \#todecacho. Salon line. 2016. Disponível em < http://www.lojadasalonline.com.br/> Acesso em 22 de jul. 2016.

RICHERS ,Raimar, Marketing uma visão brasileira, São Paulo, Negócios Editora,2000.

SAMARA, B. S.; BARROS, J. C. Pesquisa de Marketing: Conceitos e Metodologia. 3.ed. São Paulo: Prentice Hall, 2002.

SERVIÇO Brasileiro de Apoio às Micro e Pequenas Empresa. Como elaborar uma pesquisa de mercado. 2 ed. Minas Gerais: Serviço de Apoio às Micro e Pequenas Empresas, 2007.

SILVA, E. L. \& MENEZES, E. M. Metodologia da pesquisa e elaboração de dissertação. Florianópolis: LED/UFSC, 2001.

TIPOS de cacho: como identificar o seu. Cacheia, São Paulo, 17 fev. 2014. Disponível em <http://cacheia.com>. Acesso em 25 de maio 2016.

TIPOS de cabelos.Portal da Sociedade Brasileira de Dermatologia. Disponível em < http:// http://www.sbd.org.br//> Acesso em 03 de set. 2016.

TONDO, Stephanie. Cacho é bonito e lucrativo. O Dia, Rio de Janeiro, 18 abr. 2015. Disponível em: <http:// odia.ig.com.br>. Acesso em 17 de maio 2016.

WESINSTEN, Art,Segmentação de mercado: tradução Celso A . Rimoli, São Paulo,Atlas, 1995

WING, Michael J. Como falar com seus clientes: o que eles têm a contar sobre a sua empresa quando você faz as perguntas certas; tradução de Luiz Euclydes Trindade Frazão e Lenke Peres, Rio de Janeiro, Campus, 1998.

YANAZE, MitsuruHiguchi. Gestão de Marketing e Comunicação: avanços e aplicações. $2^{\circ}$ edição. - São Paulo: Saraiva, 2011.

Zamberlan, Luciano. Pesquisa de mercado. Rio Grande do Sul: Unijuí, 2008

ZIKMUND, William G. Princípios da pesquisa de marketing. São Paulo: Pioneira Thomson Learning, 2006. 